DOI: $10.19195 / 2084-5065.46 .9$

\title{
Konsensualne sposoby zakończenia procesu w sprawach o wykroczenia
}

\author{
KATARZYNA LIŻYŃSKA \\ Katedra Prawa o Wykroczeniach, Karnego Skarbowego i Gospodarczego \\ Wydział Prawa, Administracji i Ekonomii Uniwersytetu Wrocławskiego
}

Klasyczny proces karny, zmierzający do rozstrzygnięcia kwestii odpowiedzialności prawnej osoby za konkretny czyn, ustępuje ostatnio miejsca postępowaniu koncyliacyjnemu ${ }^{1}$. Podczas gdy regulację materialnoprawną cechuje na ogół większa stabilność wynikająca zjej oparcia na określonych trwałych założeniach aksjologicznych i dogmatycznych, prawo procesowe, pełniąc rolę służebną wobec prawa materialnego, oprócz celów dogmatycznych związanych z funkcją ścigania, oskarżania i sądzenia, musi zapewnić ich realizacji właściwy poziom i odpowiednie warun$\mathrm{ki}^{2}$. Ostatnio zauważalny jest wzrost znaczenia instytucji zmierzających do uproszczenia, a tym samym — skrócenia postępowania karnego, co ma miejsce nie tylko w postępowaniu karnym, ale także nabiera coraz większego znaczenia w postępowaniu w sprawach o wykroczenia. Tradycyjne rozprawy sądowe z rozbudowanym postępowaniem dowodowym są zastępowane przez krótkie posiedzenia i ograniczone postępowanie dowodowe. Dobrowolne poddanie się karze, wniosek o ukaranie bez przeprowadzania rozprawy, umorzenie postępowania po pozytywnie

${ }^{1}$ M. Zbrojewska, Dobrowolne poddanie się karze w kodeksie postępowania karnego, Białystok 2002, s. 15.

2 M. Rogacka-Rzewnicka, Oportunizm i legalizm ścigania przestęstw w świetle wspótczesnych przeobrażeń procesu karnego, Warszawa 2007, s. 237.

Nowa Kodyfikacja Prawa Karnego 46, 2017

(C) for this edition by CNS 
zakończonej mediacji — to podstawowe instytucje, w których orzeczenie sądowe jest wynikiem porozumienia między stronami postępowania, akceptowanego następnie przez sąd. Wymienione instytucje są wyrazem nowej rzeczywistości prawnej i tendencji do rozstrzygania spraw karnych w trybie porozumień procesowych oraz stosowania uproszczeń proceduralnych, w celu odciążenia sądów i zmniejszenia wydatków obciążających wymiar sprawiedliwości ${ }^{3}$. Główny cel tych postępowań w postaci przyspieszenia procesu nie budzi żadnych wątpliwości. Nie należy przy tym zapominać o innym celu konsensualnych zakończeń spraw karnych, a mianowicie większej akceptowalności orzeczeń sądów. W takich sytuacjach sąd akceptuje i zatwierdza decyzje podejmowane w rzeczywistości przez strony, oczywiście przy spełnieniu ustawowych warunków w tym zakresie. Stwarza to dodatkowe możliwości osiągnięcia porozumienia między oskarżonym a pokrzywdzonym odnośnie do naprawienia szkody wyrządzonej czynem zabronionym, prowadząc do realizacji funkcji kompensacyjnej procesu karnego, a co za tym idzie — niwelowania skutków wiktymizacji wtórnej ${ }^{4}$. Na uwagę zasługuje teza postawiona przez C. Beccarię, iż kara jest tym użyteczniejsza, im jest szybsza, ponieważ im krótszy jest czas, który upłynął między czynem przestępnym a karą, tym silniejsze i trwalsze będzie w umyśle ludzkim skojarzenie tych dwóch pojęć: przestępstwa i kary ${ }^{5}$. Teza ta jest szczególnie aktualna przy analizowaniu czynów zabronionych, jakimi są wykroczenia, postrzegane jako błahe przewinienia, wobec których szybka reakcja państwa jest najbardziej dostrzegalna.

Konsensualizm został wprowadzony do procesu karnego wraz z wejściem w życie ustawy z dnia 6 czerwca 1997 r. W ten sposób ustawodawstwo polskie w zakresie prawa karnego dołączyło do innych państw europejskich - Bułgarii, Czech, Słowenii, Włoch czy Hiszpanii. Konsensualne sposoby rozwiązywania sporów sądowych zostały przejęte także do postępowania w sprawach o wykroczenia.

3 Tak: ibidem, s. 239-240.

4 Tak: W. Jasiński, Porozumienia procesowe w znowelizowanym kodeksie postepowania karnego, „Prokuratura i Prawo” 2014, nr 10, s. 6, oraz S. Steinborn, Porozumienia w polskim procesie karnym: skazanie bez rozprawy i dobrowolne poddanie się odpowiedzialności karnej, Kraków 2005, s. 42.

5 C. Beccaria, O przestępstwach i karach, Warszawa 1959, s. 118.

Nowa Kodyfikacja Prawa Karnego 46, 2017

(C) for this edition by CNS 
Samo pojęcie konsensusu nie jest definiowane przez kodeks postępowania karnego czy kodeks postępowania w sprawach o wykroczenia. I chociaż są to pojęcia, którymi ustawodawca w zakresie postępowań karnych nie operuje, to jednak instytucje dobrowolnego poddania się karze, skazania bez rozprawy czy mediacji nie są niczym innym, jak wyrazem konsensusu. Należy pamiętać o tym, że postępowanie zmierzające do porozumienia stron konfliktu znane było już w starożytnym prawie zwyczajowym. Układy rodzin lub klanów zwaśnionych stron ${ }^{6}$ oraz rozwiązanie konfliktu, najczęściej przez zapłatę ustalonej sumy pieniężnej tytułem odszkodowania bądź zadośćuczynienia, to właśnie konsensualne rozwiązanie konfliktu. S. Steinborn za A. Światłowskim przez porozumienie rozumie umowę zawartą przez co najmniej dwóch uczestników procesu karnego, w granicach ich uprawnień, polegającą na tym, że działając w celu uzyskania dla siebie korzystnej sytuacji procesowej, a zarazem czyniąc drugiej stronie ustępstwa, osiągnęli konsensus co do pewnej kwestii mającej znaczenie dla toku procesu lub rozstrzygnięcia merytorycznego ${ }^{7}$.

Przystępując do właściwej analizy podjętego w ramach opracowania tematu, zaznaczyć należy, iż konsensualizm w wykroczeniach pojawił się wraz z uchwaleniem w dniu 24 sierpnia $2001 \mathrm{r}$. kodeksu postępowania w sprawach o wykroczenia. Kodeks przejął instytucje postępowania karnego umożliwiające konsensualny sposób rozstrzygnięcia sporu, jakim jest wykroczenie, tj. skierowania przez oskarżyciela publicznego wniosku o skazanie obwinionego bez przeprowadzenia rozprawy, dobrowolnego poddania się odpowiedzialności przez obwinionego. Rozwój konsensualizmu w sprawach karnych spowodował, iż ustawodawca zadecydował o zmianie art. 8 k.p.w. i w ten sposób do konsensualnych sposobów rozwiązywania sporów dołączyła w sprawach o wykroczenia mediacja ${ }^{8}$. Podkreślenia wymaga, iż w postępowaniu w sprawach o wykroczenie

6 Tak: M. Sczaniecki, Powszechna historia państwa i prawa, Warszawa 1985, s. $97-98$.

7 S. Steinborn, op. cit., s. 48; A. Światłowski, Koncepcja porozumień karnoprocesowych, „Państwo i Prawo” 1998, nr 2, s. 55.

8 W brzmieniu ustalonym przez ustawę o zmianie ustawy - Kodeks postępowania karnego oraz niektórych innych ustaw z 27 września 2013 r. (Dz.U., poz. 1247 ze zm.), zmiana weszła w życie z dniem 1 lipca 2015 r.

Nowa Kodyfikacja Prawa Karnego 46, 2017

(C) for this edition by CNS 
szczególnego znaczenia nabiera nakaz rozstrzygnięcia sprawy w rozsądnym terminie. Ze swej natury postępowanie to jest mniej sformalizowane i ma uproszczoną w stosunku do postępowania karnego procedurę, co jest wynikiem charakteru czynów, jakimi są wykroczenia. Ustawodawca nie odstąpił tu wszakże od dążenia do obowiązku przestrzegania prawdy materialnej i stwierdzenia winy prawomocnym orzeczeniem. Niemniej jednak, z uwagi na charakter dóbr atakowanych przez sprawców wykroczeń, stopień ich naruszenia, a także sposób realizacji znamion tych czynów zabronionych, można w pewnym uproszczeniu powiedzieć, że postępowanie wykroczeniowe powinno być w szczególności prowadzone szybko, sprawnie, a sprawca wykroczenia może i powinien oczekiwać szybkiego rozstrzygnięcia w przedmiocie jego odpowiedzialności ${ }^{9}$. Dlatego też ważną rolę odgrywać będą tu konsensualne sposoby zakończenia postępowania.

Skazanie bez rozprawy możliwe jest w dwóch trybach inicjowanych przez odmienne strony procesowe. Inicjatorem może być oskarżyciel publiczny, który zamieści we wniosku o ukaranie wniosek o skazanie obwinionego bez rozprawy. Obwiniony może zainicjować ten skrócony tryb rozprawy, gdy po wezwaniu go na rozprawę lub zawiadomieniu o jej terminie, jeżeli nie dotyczy go wniosek o skazanie, wystąpi do sądu z wnioskiem o skazanie go w określony sposób bez przeprowadzenia rozprawy w trybie art. $58 \S 3$ k.p.w. ${ }^{10}$ Już w tym miejscu należy zaznaczyć, że obwiniony do chwili zakończenia pierwszego przesłuchania na

9 J. Karaźniewicz, Instytucje stużace uproszczeniu postępowania w sprawach o wykroczenia w świetle obowiąujacego prawa i projektowanych zmian Kodeksu postępowania w sprawach o wykroczenia, [w:] Współczesne problemy wykroczeń, red. I. Nowicka, A. Sadło-Nowak, Szczytno 2013, s. 11-12.

10 Zwrócić należy uwagę, iż umiejscowienie przez ustawodawcę zapisu o możliwości zainicjowania skróconej rozprawy w art. 58 § 3 k.p.w. wskazuje jednoznacznie, iż obwiniony może złożyć taki wniosek, gdy wniosek o ukaranie złożył oskarżyciel publiczny, a nie oskarżyciel posiłkowy w trybie art. 27 § 1 i 2 k.p.w. Tak m.in.: P. Gensikowski, Postepowanie w sprawach o wykroczenia. Komentarz, Warszawa 2017, s. 254; T. Grzegorczyk, Kodeks postępowania w sprawach o wykroczenia, wyd. 5, Warszawa 2012, s. 233. Innego zdania jest J. Karaźniewicz, która stwierdza, iż ,wniosek taki może być złożony również w sytuacji, w której podmiotem kierującym wniosek o ukaranie nie jest oskarżyciel publiczny, lecz oskarżyciel posiłkowy, któremu ustawodawca nie przyznał możliwości wystąpienia z wnioskiem o skazanie obwinionego bez rozprawy". Opinia ta jest jednak odosobniona — J. Karaźniewicz, op. cit., s. 15.

Nowa Kodyfikacja Prawa Karnego 46, 2017

(C) for this edition by CNS 
rozprawie może złożyć wniosek o ukaranie go i wymierzenie określonej kary w trybie art. 73 k.p.w., bez przeprowadzenia postępowania dowodowego, co niewątpliwie służy także skróceniu i uproszczeniu postępowania. We wszystkich jednak sytuacjach, niezależnie od inicjatora, skrócenie postępowania i przychylenie się sądu do wniosku stron możliwe jest przy spełnieniu przesłanek podmiotowo-przedmiotowych. Przy czym, jak podkreśla Sąd Najwyższy, spełnienie kumulatywne przesłanek podmiotowych i przedmiotowych nie obliguje niejako z automatu, a jedynie uprawnia oskarżyciela publicznego do wystąpienia z wnioskiem o skazanie bez rozprawy ${ }^{11}$.

W pierwszej ze wskazanych sytuacji, kiedy to oskarżyciel publiczny występuje do sądu z wnioskiem o skazanie obwinionego bez przeprowadzenia rozprawy, złożenie takiego wniosku następuje jeszcze przed formalnym wszczęciem postępowania przez sąd. Obwinionemu przedstawiono już, co prawda, zarzuty, zatem mógł skorzystać z przysługujących mu uprawnień w postaci złożenia wyjaśnień bądź odmowy ich złożenia. Mógł składać wnioski dowodowe, które dały podstawę do skierowania przez oskarżyciela publicznego wniosku o ukaranie, a przez to wpływać na przebieg postępowania w ramach czynności wyjaśniających. Mógł także złożyć oświadczenie o chęci poddania się za popełniony czyn karze bądź kara — zgodna z dyrektywami jej wymierzania - mogła zostać obwinionemu zaproponowana przez oskarżyciela publicznego, a obwiniony zaproponowaną karę mógł zaakceptować. Ta zgoda obwinionego ma znaczenie dla zakończenia postępowania wykroczeniowego. Wyznacza bowiem granicę konsensusu pomiędzy stronami postępowania — obwinionym i oskarżycielem publicznym. Zgoda może zostać wyrażona w protokole przesłuchania obwinionego lub zostać złożona w odrębnym piśmie. Musi być ona jednak wyraźna i jednoznaczna w zakresie wymierzenia określonej w oświadczeniu kary. Nie może to być natomiast zgoda na złożenie samego wniosku. Zgoda obwinionego może zostać cofnięta do momentu rozpoznania wniosku przez sąd. Należy podkreślić, iż brak jest zakazu skorzystania w tym trybie z możliwości, jakie daje ustawodawca w art. $39 \S 1$ k.w., tj. nadzwyczajnego złagodzenia kary

11 Zob. postanowienie SN z 24 kwietnia 2007 r., IV KZ 276/06, OSNwSK 2007, nr 1, poz. 916.

Nowa Kodyfikacja Prawa Karnego 46, 2017

(C) for this edition by CNS 
przez wymierzenie kary poniżej dolnej granicy ustawowego zagrożenia albo kary łagodniejszego rodzaju ${ }^{12}$, wręcz przeciwnie — ustawodawca w art. $58 \S 1$ k.p.w. wprost wskazuje na taką możliwość. Należy jednak zwrócić uwagę, że skoro ustawodawca daje możliwość złożenia wniosku o skazanie na karę uzgodnioną pomiędzy stronami, to nie daje możliwości w tym trybie rezygnacji ze stosowania wszelkich środków reakcji karnej, tj. odstąpienia od wymierzenia kary i środka karnego dopuszczalnego w trybie art. 39 § 1 k.w. Wniosek dotyczy przecież wymierzenia obwinionemu określonej kary lub środka karnego, a nie uzgodnionego z obwinionym niestosowania wobec niego żadnej reakcji karnej ${ }^{13}$. Innego zdania jest P. Gensikowski, który twierdzi, że nie ma przeszkód, aby wniosek o skazanie bez rozprawy obejmował odstąpienie od wymierzenia kary i środka karnego, a więc całkowite odstąpienie od ukarania ${ }^{14}$.

Przesłanką przedmiotową jest niebudzące wątpliwości sprawstwo obwinionego co do zarzucanego mu czynu, potwierdzone zgromadzonym w sprawie materiałem dowodowym, jak również osiągnięcie celów postępowania mimo nieprzeprowadzenia rozprawy w całości. Obie te przesłanki podlegają weryfikacji najpierw przez oskarżyciela publicznego przed skierowaniem wniosku do sądu, a następnie przez sąd. Dopiero uwzględnienie wniosku o skazanie bez przeprowadzenia rozprawy przez sąd stanowić będzie o skuteczności uzgodnień pomiędzy stronami postępowania. Bez wątpienia, stanowiąc o osiągnięciu celów postępowania, ustawodawca wskazuje na cele wymienione w art. $2 \S 1$ k.p.k., który poprzez art. 8 k.p.w. ma zastosowanie w postępowaniu w sprawach o wykroczenia. Chodzi zatem o to, by sprawca został wykryty i pociągnięty do odpowiedzialności, umocnione zostało poszanowanie prawa

12 Por. wyrok SN z 4 października 2006 r., II K 8/06, OSNwSK 2006, nr 1, poz. 1871; J. Lewiński, Kodeks postepowania w sprawach o wykroczenia. Komentarz, Warszawa 2011, s. 192. T. Grzegorczyk wskazuje, iż w początkowej wersji Zespół ds. ujednolicenia prawa wykroczeń zakładał możliwość ukarania sprawcy wykroczenia, w trybie złożenia wniosku przez oskarżyciela publicznego bez przeprowadzenia rozprawy, karą grzywny nie wyższą niż 5000 zł (przy założeniu, że górna granica kary grzywny będzie wynosiła 10000 zf) lub karą nagany, ograniczenia się do środka karnego bądź ze wskazaniem zastosowania nadzwyczajnego złagodzenia kary, jako iż skazanie to miało być przejawem „skazania typu złagodzonego” - T. Grzegorczyk, op. cit., s. 231.

13 T. Grzegorczyk, op. cit., s. 232.

14 P. Gensikowski, op. cit., s. 251.

Nowa Kodyfikacja Prawa Karnego 46, 2017

(C) for this edition by CNS 
i zasad współżycia społecznego przez trafne zastosowanie kar i środków karnych, co ma służyć zwalczaniu wykroczeń oraz zapobieganiu im, oraz by uwzględnione zostały prawnie chronione interesy pokrzywdzonego, a rozstrzygnięcie sprawy nastąpiło w rozsądnym terminie. Jeżeli wskazane cele zostaną osiągnięte, mimo nieprzeprowadzenia rozprawy, przy spełnieniu innych wymienionych przesłanek z art. 58 § 1 i 2 k.p.w., oskarżyciel publiczny w celu usprawnienia postępowania może złożyć taki wniosek. Nie budzi wątpliwości, że przedmiotem porozumienia nie może być kwalifikacja prawna czynu ${ }^{15}$, która oceniona winna być przez organ prowadzący czynności wyjaśniające, posiadający odpowiednią wiedzę w tym zakresie, i nie może ona podlegać negocjacjom.

Wniosek oskarżyciela publicznego o skazanie bez przeprowadzenia rozprawy stanowi element wniosku o ukaranie. Powinien być umieszczony w końcowej części wniosku, po podaniu danych wskazanych w art. 57 $\S 2$ pkt 1-3 i § 3 k.p.w., a przed podpisem wnioskodawcy. Nie powinien być formułowany na początku wniosku o ukaranie, gdyż ma on jednocześnie określać sposób skazania, a nie wydaje się prawidłowe żądanie określonego skazania za coś, co dopiero później będzie opisane ${ }^{16}$.

Sąd, rozpoznając wniosek o skazanie bez przeprowadzenia rozprawy, nie jest uprawniony do dokonywania zmian w jego treści, gdyż naruszałoby to warunki ugody zawartej wcześniej między oskarżycielem a obwinionym ${ }^{17}$. Potrzeba zaś dokonania jakichkolwiek zmian w treści tej ugody, czy to na korzyść, czy na niekorzyść obwinionego, uzależniona jest od dokonania modyfikacji treści wniosku przez strony, a w sytuacji braku takiej modyfikacji czy sprzeciwu którejkolwiek ze stron wobec modyfikacji nie zachodzą podstawy do uwzględnienia wniosku i obowiązkiem sądu jest skierowanie sprawy na drogę postępowania na zasadach ogólnych ${ }^{18}$. Oznacza to, że dysponentem zgody na orzeczenie określonej kary, mimo

15 Tak: R.A. Stefański, Wniosek prokuratora o skazanie oskarżonego bez rozprawy, „Prokuratura i Prawo” 1998, nr 2, s. 48.

16 T. Grzegorczyk, op. cit., s. 231.

17 Tak: wyrok SA w Krakowie z 26 listopada 2013 r., sygn. II AKa 231/13, Legalis 747080; co prawda orzeczenie to dotyczy skazania bez przeprowadzenia rozprawy za przestępstwo, jednak tożsama sytuacja występuje na gruncie postępowania wykroczeniowego.

18 Zob. wyrok SN z 15 października 2013 r., sygn. III K 265/13, Legalis 737828.

Nowa Kodyfikacja Prawa Karnego 46, 2017

(C) for this edition by CNS 
przekazania wniosku do rozpoznania sądowi, pozostaje obwiniony, co stanowi należyte zabezpieczenie jego interesów. Takie rozwiązanie jest gwarancją uwzględnienia zdania obwinionego. W sytuacji, gdyby zgoda obwinionego na modyfikację nie miała żadnego znaczenia dla dalszego procedowania nad wnioskiem, nie można by było mówić o jakimkolwiek porozumieniu $^{19}$.

Uwzględnienie wniosku o skazanie bez rozprawy, po stwierdzeniu spełnienia wszystkich określonych prawem warunków, skutkuje wydaniem wyroku na posiedzeniu, z pominięciem więc najbardziej czasochłonnej fazy postępowania w sprawach o wykroczenie, jaką jest rozprawa ${ }^{20}$.

Kolejną instytucją zaliczaną do trybów konsensualnych w postępowaniu w sprawach o wykroczenia jest skazanie bez przeprowadzenia w całości postępowania dowodowego. Inicjatywa w tym zakresie leży po stronie obwinionego. To on, do chwili zakończenia pierwszego przesłuchania na rozprawie, może złożyć wniosek w trybie art. 73 k.p.w. o skazanie go w określony sposób, bez przeprowadzania postępowania dowodowego. Co prawda, ustawodawca nie wskazuje terminu początkowego, w którym obwiniony może złożyć taki wniosek, ale wydaje się, z uwagi na uprawnienia obwinionego wynikające z art. 58 § 3 k.p.w., że wniosek w trybie art. 73 k.p.w. może zostać złożony od chwili otwarcia przewodu sądowego. Uprawnienie do złożenia przedmiotowego wniosku przysługuje obwinionemu zarówno w sytuacji, gdy wniosek o ukaranie został złożony przez oskarżyciela publicznego, jak i w sytuacji, gdy wniosek został złożony przez oskarżyciela posiłkowego w trybie art. $27 \S 1$ i 2 k.p.w. ${ }^{21}$ Wniosek o skazanie w swojej treści winien zawierać, po pierwsze, zgodę na wydanie wyroku skazującego, po drugie, propozycję w zakresie skazania, po trzecie, akceptację wydania wyroku bez przeprowadzenia postępowania dowodowego bezpośrednio przed sądem ${ }^{22}$. Tak jak w przypadku wniosku oskarżyciela o skazanie bez rozprawy, tak i w tej sytuacji wina i sprawstwo obwinionego nie mogą budzić wątpliwości. Wątpliwości nie

19 Tak: K. Urbanowicz, Formy konsensualizmu procesowego $w$ świetle ostatnich nowelizacji Kodeksu postępowania karnego, „Zeszyt Studencki Kół Naukowych Wydziału Prawa i Administracji UAM" 2016, nr 2, s. 264.

20 J. Karaźniewicz, op. cit., s. 17.

21 Tak: P. Gensikowski, op. cit., s. 307; T. Grzegorczyk, op. cit., s. 274.

22 J. Karaźniewicz, op. cit., s. 17.

Nowa Kodyfikacja Prawa Karnego 46, 2017

(C) for this edition by CNS 
mogą też budzić okoliczności popełnienia wykroczenia. Brak wątpliwości winien dotyczyć wykroczenia zarzucanego obwinionemu i odnosić się do realizacji wszystkich niezbędnych znamion tego czynu, a w konsekwencji jego kwalifikacji prawnej, rodzaju i stopnia zawinienia, skutku przestępnego działania, rozmiaru wyrządzonej szkody, które mają wpływ na kształt i rozmiar odpowiedzialności obwinionego ${ }^{23}$. Propozycja odnośnie do rodzaju i wysokości kary leży w tej sytuacji w gestii obwinionego. W przeciwieństwie do wniosku złożonego w trybie art. $58 \S 1$ k.p.w. oskarżyciel publiczny nie bierze tutaj udziału w uzgadnianiu z obwinionym rodzaju i wysokości kary. To obwiniony proponuje:

— jedną z kar określonych w katalogu kar z art. 18 k.w.;

— jedną z kar określonych w katalogu kar z art. 18 k.w. połączoną z orzeczeniem środka karnego przewidzianego w art. 28 k.w.;

— jedną z kar określonych w katalogu kar z art. 18 k.w. z odstąpieniem od orzeczenia środka karnego na podstawie art. $39 \S 1$ k.w. ${ }^{24}$

Uwzględnienie wniosku możliwe jest w sytuacji, gdy oskarżyciel publiczny i oskarżyciel posiłkowy, prawidłowo zawiadomieni o terminie rozprawy, nie zgłoszą w tym zakresie sprzeciwu. Należy pamiętać, że brak stanowiska oskarżyciela w przedmiocie sprzeciwu na wniosek obwinionego o skazanie go bez przeprowadzenia postępowania dowodowego nie stoi na przeszkodzie do uwzględnienia wniosku. Wymogiem jest jednak prawidłowe zawiadomienie o terminie rozprawy. Brak akceptacji zarówno oskarżyciela publicznego, jako rzecznika interesu społecznego, jak i oskarżyciela posiłkowego, wyrażony w ich sprzeciwie, wiąże się albo z koniecznością dokonania zmian we wniosku za aprobatą obwinionego, albo z odmową uwzględnienia wniosku przez sąd. Przyczyny odmowy uwzględnienia wniosku o skazanie obwinionego mogą dotyczyć wszystkich wymogów procesowych — zarówno wątpliwości co do okoliczności popełnienia czynu, sprawstwa i winy obwinionego, sprzeciwu oskarżyciela publicznego oraz oskarżyciela posiłkowego, jak i nieosiągnięcia celów postępowania wyrażonych w art. 2 § 1 k.p.k. Uwzględnienie przedmiotowego wniosku przez sąd skutkować będzie z pewnością skróceniem

23 Tak: SN w wyroku z 4 października 2013 r., sygn. akt III KK 168/13, Legalis 739688; co prawda Sąd Najwyższy w uzasadnieniu odnosił się do trybu z art. 387 k.p.k., jednak rozważania te przystają także do trybu z art. 73 k.p.w.

24 P. Gensikowski, op. cit., s. 307.

Nowa Kodyfikacja Prawa Karnego 46, 2017

(C) for this edition by CNS 
procedowania, gdyż po wydaniu postanowienia o uwzględnieniu wniosku obwinionego o skazanie sąd wydaje postanowienie o uznaniu materiału dowodowego za ujawniony i zamyka przewód sądowy. Po raz kolejny korzystne porozumienie wpływa na sprawność i efektywność postępowania.

Do przejawów konsensualizmu procesowego zaliczyć należy także mediację, która została wprowadzona do postępowania w sprawach o wykroczenia stosunkowo niedawno, dopiero bowiem z dniem 1 lipca 2015 r., chociaż w postępowaniu karnym znana już była, w swej pierwotnej formie, od 1997 r. Przez wprowadzenie mediacji zaakcentowano cel postępowania uwzględniający prawnie chronione interesy pokrzywdzonego. Dotychczasowa, zdominowana przez interes państwa, filozofia karania, która sprowadzała się w istocie do ukarania sprawcy, a także niedoceniania restytucji i kompensacji oraz pomijania ważnej roli konfliktu społecznego, jaki powstał pomiędzy sprawcą a pokrzywdzonym wskutek czynu zabronionego, zmienia się ${ }^{25}$, co uznać należy za słuszne. W literaturze podkreśla się zmierzch dotychczasowego paradygmatu prawa karnego i zastąpienie go restytucją na rzecz pokrzywdzonego ${ }^{26}$. Mediacja to dobrowolne, bezstronne i poufne rozstrzygnięcie konfliktu przez osobę trzecią, które pozwala na uwzględnienie woli obu zainteresowanych stron $^{27}$. W przeciwieństwie do instytucji wskazanych uprzednio mediacja to porozumienie przede wszystkim obwinionego i pokrzywdzonego, którego konsekwencją może być rozwiązanie sporu, jakim jest wykroczenie, a następnie ugodowe zakończenie postępowania z pozytywnymi skutkami dla każdej ze stron postępowania. Udział pokrzywdzonego w mediacji ma szczególne znaczenie — może w łatwiejszy i szybszy sposób uzyskać od sprawcy zadośćuczynienie o różnym, adekwatnym do danej sytuacji charakterze, tj. materialnym, moralnym, psychicznym ${ }^{28}$. Sprawcy pozwala uświadomić sobie krzywdę, jaką wyrządził pokrzywdzonemu, ma on możliwość wyrażenia skruchy, uzgodnienia formy i czasu niezbędnego do

25 Uzasadnienie rzadowego projektu Kodeksu karnego, [w:] Nowe Kodeksy karne z 1997 r. z uzasadnieniem, Warszawa 1997, s. 146.

26 Zob. K. Liżyńska, J. Żylińska, Mediacja w sprawach o wykroczenia - wnioski de lege ferenda, „ADR Arbitraż i Mediacja” 2012, nr 2, s. 125 i cyt. tam literatura.

27 R. Citowicz, T. Fedorszczak, Kilka uwag na temat mediacji w sprawach karnych, „ADR Arbitraż i Mediacja” 2008, nr 2, s. 4.

28 A. Rękas, Mediacja w polskim prawie karnym, Warszawa 2011, s. 15.

Nowa Kodyfikacja Prawa Karnego 46, 2017

(C) for this edition by CNS 
naprawienia szkody. Przepis art. 23a § 1 k.p.k., który przez wspomniany wcześniej art. 8 k.p.w. ma zastosowanie w sprawach o wykroczenia, wyraźnie wskazuje, iż to sąd lub referendarz sądowy, a w czasie wykonywania czynności wyjaśniających organ prowadzący to postępowanie, może z inicjatywy lub za zgodą pokrzywdzonego i obwinionego skierować sprawę do instytucji lub osoby godnej zaufania w celu przeprowadzenia postępowania mediacyjnego między pokrzywdzonym i obwinionym, o czym się ich poucza, informując o celach i zasadach tego postępowania. Sposób przeprowadzania mediacji reguluje rozporządzenie Ministra Sprawiedliwości z 7 maja 2015 r. w sprawie postępowania mediacyjnego w sprawach karnych ${ }^{29}$. W razie skutecznej mediacji możliwe będzie nawet zrezygnowanie przez oskarżyciela publicznego z występowania z wnioskiem o ukaranie na podstawie art. 41 in fine k.w., jeżeli miało to miejsce jeszcze w ramach czynności wyjaśniających, bądź zastosowanie przez sąd nadzwyczajnego złagodzenia kary lub odstąpienie od jej wymierzenia $(\text { art. } 39 \text { k.w.) })^{30}$. Instrument ten, jako alternatywny sposób rozwiązywania sporów, ma wiele zalet, podobnie bowiem jak tryby konsensualne, pozwala w większej mierze na uwzględnienie interesów podmiotów bezpośrednio zainteresowanych ostatecznym wynikiem sprawy ${ }^{31}$.

Tryby konsensualne mają wiele zalet zarówno dla wymiaru sprawiedliwości, jak i dla samych stron postępowania. Analiza zmian w przepisach proceduralnych w sprawach o wykroczenia prowadzi do wniosku, że ustawodawca wciąż rozszerza możliwości konsensualnego zakończenia postępowania. Zmiany te zasługują na aprobatę, albowiem przede wszystkim w postępowaniu w sprawach o wykroczenia szybkość postępowania ma znaczenie niebagatelne. Szybka reakcja państwa na drobny czyn, jakim jest wykroczenie, stanowi wypełnienie celów postępowania, a wymierzona sprawcy kara w niedalekiej odległości od popełnienia czynu pozwala mu zrozumieć naganność postępowania i zaakceptować karę, na której wymiar przy konsensualnych sposobach zakończenia postępowania obwiniony ma wpływ. Przyspieszenie postępowania przez nieprzeprowa-

29 Dz.U. z 2015 r., poz. 716.

30 J. Żylińska, Mediacja — nowa instytucja w sprawach o wykroczenia, [w:] Wspótczesne problemy wykroczeń. Materialnoprawna i procesowa problematyka wykroczeń, Szczytno 2016, s. 189.

31 K. Urbanowicz, op. cit., s. 270.

Nowa Kodyfikacja Prawa Karnego 46, 2017

(C) for this edition by CNS 
dzenie rozprawy bądź nieprzeprowadzenie postępowania dowodowego w całości z pewnością usprawniają działanie wymiaru sprawiedliwości. Nie bez znaczenia pozostaje odciążenie finansowe związane z przeprowadzeniem całego postępowania dowodowego w ramach rozprawy. Ważnym aspektem jest to, że ustawodawca upraszczając postępowanie, nie pominął roli pokrzywdzonego, a tym samym zaakcentował jeden z podstawowych celów postępowania, jakim jest ochrona prawnie chronionych interesów pokrzywdzonego i związana z nim restytucja. Pokrzywdzony przez porozumienie może liczyć, iż szkoda wyrządzona wykroczeniem zostanie naprawiona i pomniejszona, czy wręcz zniesione zostaną skutki wiktymizacji. Tryby konsensualne wydają się więc dobrym rozwiązaniem. Rodzą jednak niebezpieczeństwo zbyt pobieżnej analizy sprawy w celu zakończenia postępowania. Niezależnie od wszelkich uproszczeń, na jakie pozwala ustawodawca, skrócenie postępowania nie może oznaczać odstąpienia od dążenia do prawdy obiektywnej. Dlatego ważne jest, by sąd, a wcześniej oskarżyciel publiczny, wnikliwie koncypował w zakresie czynu zarzucanego sprawcy i okoliczności jego popełnienia, a rezygnacja z przeprowadzenia rozprawy czy postępowania dowodowego musi wynikać z rzetelnej analizy materiału dowodowego potwierdzającego bez żadnych wątpliwości winę i sprawstwo obwinionego w zakresie zarzucanego mu czynu. Od wymiaru sprawiedliwości wymaga się wciąż efektywności, sprawności i szybkiego rozstrzygania, co bez form konsensualnych byłoby znacznie utrudnione. Tryby konsensualne stanowią więc pewien kompromis między skutecznym działaniem sądów i realizowaną przez nie zasadą szybkości postępowania a takimi zasadami procesu, jak zasada legalizmu, bezpośredniości czy jawności ${ }^{32}$, o których zapominać nie można.

\section{Consensual ways of terminating trials in the cases regarding petty offences}

\section{Summary}

The noticeable increase in the importance of consensus in criminal proceedings including cases of petty offences, prompted reflection on the institutions allowing legal proceedings to be terminated without full evidence investigation. Undoubtedly, this sim-

32 Ibidem, s. 273.

Nowa Kodyfikacja Prawa Karnego 46, 2017

(C) for this edition by CNS 
plification affects the pace of legal proceedings, and hence their economy. However, we cannot also overlook its influence on the more efficient implementation of the compensation function of a trial, as well as the greater subjective acceptability of the judicial decision by the parties of legal proceedings. The author of the following paper analyzes institutions of consensual resolving of disputes in legal proceedings concerning petty offences, pointing to the pros and cons of applying such a solution.

Keywords: consensual ways, perpetrator, rights, mediation, the conflict penalty. 